\title{
Natural Transformation as a Mechanism of Horizontal Gene Transfer in Aliarcobacter butzleri
}

\author{
Marina Bonifácio ${ }^{1}$, Cristiana Mateus ${ }^{1}$, Ana R. Alves ${ }^{1}$, Emanuel Maldonado ${ }^{\mathbb{D}}$, Ana P. Duarte ${ }^{1,2} \mathbb{D}_{\text {, }}$ \\ Fernanda Domingues ${ }^{1}$, Mónica Oleastro ${ }^{3}$ (D) and Susana Ferreira ${ }^{1, *(\mathbb{D})}$
}

1 CICS-UBI-Health Sciences Research Centre, University of Beira Interior, 6201-506 Covilhã, Portugal; marina_acb@hotmail.com (M.B.); cristiana.lopes.mateus@ubi.pt (C.M.); ritalves95@gmail.com (A.R.A.); apcd@ubi.pt (A.P.D.); fcd@ubi.pt (F.D.)

2 C4-UBI-Cloud Computing Competence Centre, University of Beira Interior, 6200-284 Covilhã, Portugal; eman.maldonado@gmail.com

3 National Reference Laboratory for Gastrointestinal Infections, Department of Infectious Diseases, National Institute of Health Dr. Ricardo Jorge, 1649-016 Lisbon, Portugal; monica.oleastro@insa.min-saude.pt

* Correspondence: susana.ferreira@fcsaude.ubi.pt

check for updates

Citation: Bonifácio, M.; Mateus, C.; Alves, A.R.; Maldonado, E.; Duarte, A.P.; Domingues, F.; Oleastro, M.; Ferreira, S. Natural Transformation as a Mechanism of Horizontal Gene Transfer in Aliarcobacter butzleri. Pathogens 2021, 10, 909. https:// doi.org/10.3390/pathogens10070909

Academic Editors: Carmelo Biondo and Lawrence S. Young

Received: 14 May 2021

Accepted: 15 July 2021

Published: 19 July 2021

Publisher's Note: MDPI stays neutra with regard to jurisdictional claims in published maps and institutional affiliations.

Copyright: (c) 2021 by the authors. Licensee MDPI, Basel, Switzerland. This article is an open access article distributed under the terms and conditions of the Creative Commons Attribution (CC BY) license (https:// creativecommons.org/licenses/by/ $4.0 /)$

\begin{abstract}
Aliarcobacter butzleri is an emergent enteropathogen, showing high genetic diversity, which likely contributes to its adaptive capacity to different environments. Whether natural transformation can be a mechanism that generates genetic diversity in A. butzleri is still unknown. In the present study, we aimed to establish if $A$. butzleri is naturally competent for transformation and to investigate the factors influencing this process. Two different transformation procedures were tested using exogenous and isogenic DNA containing antibiotic resistance markers, and different external conditions influencing the process were evaluated. The highest number of transformable A. butzleri strains were obtained with the agar transformation method when compared to the biphasic system (65\% versus $47 \%$ ). A. butzleri was able to uptake isogenic chromosomal DNA at different growth phases, and the competence state was maintained from the exponential to the stationary phases. Overall, the optimal conditions for transformation with the biphasic system were the use of $1 \mu \mathrm{g}$ of isogenic DNA and incubation at $30^{\circ} \mathrm{C}$ under a microaerobic atmosphere, resulting in a transformation frequency $\sim 8 \times 10^{-6}$ transformants/CFU. We also observed that $A$. butzleri favored the transformation with the genetic material of its own strain/species, with the DNA incorporation process occurring promptly after the addition of genomic material. In addition, we observed that A. butzleri strains could exchange genetic material in co-culture assays. The presence of homologs of well-known genes involved in the competence in the A. butzleri genome corroborates the natural competence of this species. In conclusion, our results show that A. butzleri is a naturally transformable species, suggesting that horizontal gene transfer mediated by natural transformation is one of the processes contributing to its genetic diversity. In addition, natural transformation can be used as a tool for genetic studies of this species.
\end{abstract}

Keywords: Aliarcobacter butzleri; natural competence; transformation

\section{Introduction}

The historically developed genus Arcobacter was proposed by Vandamme in 1991 as belonging to the class Epsilonproteobacteria and the family Campylobacteraceae [1]. Nonetheless, recently, a taxonomic reassessment of this genus was proposed, which was transferred to the Arcobacteraceae family, and it was divided into six genera, including the Aliarcobacter genus [2,3]. This later is a widespread and diverse genus, with the species Aliarcobacter butzleri, Aliarcobacter cryaerophilus, Aliarcobacter skirrowii and Aliarcobacter thereius being frequently associated with human and animal disease [4-6]. Amongst these species, A. butzleri is the fourth most frequently found Campylobacter-like-organism in human diarrheal stool samples [7-9] and one of the most frequently isolated bacterial pathogens in fecal 
samples from individuals with acute enteric disease [6]. Beyond its association with human diseases, this species has a wide distribution through the environment-animal-human web [5]. This may be associated with a high adaptive capacity, which, in turn, may be related to the high diversity of its genome, a consequence of the genomic plasticity and cellular responses $[5,10]$. One of the strategies for bacterial evolution is the acquisition and incorporation of foreign genetic material through horizontal gene transfer (HGT) [11]. HGT can occur by different processes, such as conjugation, transduction or natural transformation [12,13]. Natural transformation is a process characterized by the absorption, incorporation and functional expression by bacteria of extracellular DNA, which is free and often abundant in the environment and hosts [11,14]. Besides the possible benefits of natural transformation in accelerating bacterial adaptation, the acquired DNA could be used for other processes, such as nutrient supply, and genetic material for the repair of DNA damage [15]. Natural competence for transformation is recognized for more than 80 bacterial species [16], including for Campylobacter genus that is closely related to Aliarcobacter. The frequency of natural transformation for Campylobacter is described to reach up to $10^{-3}$ transformants/CFU, being the most effective form of HGT reported for this species, with a greater affinity for acquiring DNA from siblings [17-20]. Campylobacter jejuni is competent under ideal growth conditions, with natural transformation being influenced by environmental conditions and physiological processes $[18,20]$.

However, little is known regarding the natural transformation ability of A. butzleri, even though whole-genome sequencing of $A$. butzleri has revealed several putative competence genes [10]. In the present study we aimed to characterize and advance in the understanding of the natural transformation in A. butzleri while contributing to improving the genetic manipulation of this bacterium.

\section{Results}

2.1. Screening for Aliarcobacter butzleri Isolates with Detectable Levels of Natural Transformation

To investigate the natural competence in A. butzleri, we started with a screening of 17 non-related $A$. butzleri strains obtained from different sources and different genetic backgrounds [21] (Table 1). The natural transformation was carried out by two different methodologies: an agar transformation method and a biphasic system method. As donor DNA, the total genomic DNA from an A. butzleri mutant strain, possessing a kanamycin resistance marker inserted in the $\operatorname{are} B$ gene, coding for an inner membrane protein of an efflux pump system (DQ40A1 $\triangle a r e B:: k^{R}{ }^{R}$ ) was used. Amongst the 17 strains evaluated, 11 $(65 \%)$ were found to be transformable with the agar transformation method and eight $(47 \%)$ with the biphasic system. For the remaining six strains, no detectable levels of natural transformation were observed in the tested conditions (Table 1). In general, a higher number of transformants were obtained with the agar transformation method (a median value of 61 transformants) than with the biphasic system (a median value of 15 transformants). There were, however, two exceptions for which more than 500 transformants were obtained with the biphasic method, the DQ40A1 strain, corresponding to the native strain from the mutant used as a donor, and the CR1132 strain. In the control assays, where no donor DNA was added, no mutants were detected. In order to confirm the transformation event, the insertion of the kanamycin resistance marker was confirmed by PCR. Following this first screening, the A. butzleri DQ40A1 strain showed high transformation frequency and was therefore selected for additional studies, including a genomic analysis. 
Table 1. Aliarcobacter butzleri strains and transformation frequencies.

\begin{tabular}{|c|c|c|c|c|c|}
\hline $\begin{array}{c}\text { Recipient } \\
\text { A. butzleri Strain }\end{array}$ & Origin/Year of Isolation & $\mathrm{ST}^{\mathrm{a}}$ & $\begin{array}{l}\text { Resistance } \\
\text { Profile }^{\mathrm{a}}\end{array}$ & $\begin{array}{c}\text { Agar Transformation } \\
\text { Method }\end{array}$ & $\begin{array}{c}\text { Biphasic System } \\
\text { Method }\end{array}$ \\
\hline 1426_2003 & $\begin{array}{l}\text { Diarrheic human } \\
\text { stool/2003 }\end{array}$ & 47 & NAL, CTA $^{b}$ & ++- & -- \\
\hline Ab_1711 & $\begin{array}{l}\text { Poultry slaughterhouse } \\
\text { equipment surface/2011 }\end{array}$ & ST_new1 & $\begin{array}{l}\text { LEV, CIP, NAL, } \\
\text { CTA }\end{array}$ & -- & -- \\
\hline Ab_2211 & $\begin{array}{l}\text { Slaughterhouse } \\
\text { surface/2011 }\end{array}$ & 460 & $\begin{array}{l}\text { AMP, NAL, } \\
\text { CTA }\end{array}$ & -- & -- \\
\hline $\mathrm{Ab} \_2811$ & $\begin{array}{c}\text { Poultry carcass neck } \\
\text { skin/2011 }\end{array}$ & 107 & $\begin{array}{l}\text { AMP, ERY, LEV, } \\
\text { CIP, NAL, CTA }\end{array}$ & -++ & +-- \\
\hline Ab_4211 & $\begin{array}{l}\text { Poultry carcass } \\
\text { drippings / } 2011\end{array}$ & ST_new2 & $\begin{array}{l}\text { AMP, LEV, CIP, } \\
\text { NAL, CTA }\end{array}$ & +++ & -++ \\
\hline Ab_4511 & $\begin{array}{l}\text { Poultry carcass } \\
\text { drippings/2011 }\end{array}$ & 510 & $\begin{array}{l}\text { AMP, NAL, } \\
\text { CTA }\end{array}$ & ++- & +++ \\
\hline CR424 & Poultry meat/2015 & ST_new3 & $\begin{array}{l}\text { AMP, ERY, } \\
\text { NAL, CTA }\end{array}$ & -- & -- \\
\hline CR502 & Poultry meat/2015 & ST_new4 & $\begin{array}{l}\text { ERY, LEV, CIP, } \\
\text { NAL, CTA }\end{array}$ & -- & -- \\
\hline CR604 & Beef meat/2015 & ST_new5 & NAL, CTA & +++ & +++ \\
\hline CR641 & Poultry meat/2015 & 108 & $\begin{array}{l}\text { ERY, NAL, } \\
\text { CTA }\end{array}$ & +-- & -- \\
\hline CR891 & Poultry meat/2016 & 94 & NAL, CTA & --- & --- \\
\hline CR892 & Poultry meat/2016 & ST_new6 & $\begin{array}{l}\text { AMP, LEV, CIP, } \\
\text { NAL, CTA }\end{array}$ & +++ & -+- \\
\hline CR1132 & $\begin{array}{c}\text { Ready-to-eat } \\
\text { vegetables/2016 }\end{array}$ & ST_new7 & NAL, CTA & +++ & +++ \\
\hline CR1143 & Poultry meat/2016 & ST_new8 & $\begin{array}{l}\text { AMP, LEV, CIP, } \\
\text { NAL, CTA }\end{array}$ & +++ & +-+ \\
\hline DQ20dA1 & Goat milk/2015 & ST_new9 & $\begin{array}{l}\text { AMP, LEV, CIP, } \\
\text { NAL, CTA }\end{array}$ & -- & -- \\
\hline DQ31A1 & Sheep milk/2015 & 172 & $\begin{array}{l}\text { AMP, NAL, } \\
\text { CTA }\end{array}$ & +++ & --- \\
\hline DQ40A1 & $\begin{array}{l}\text { Dairy plant equipment } \\
\text { surface/2015 }\end{array}$ & ST_new10 & NAL, CTA & +++ & +++ \\
\hline
\end{tabular}

NT-non-transformable at the tested conditions; +- considering three independent replicates, the strain was transformed once; ++twice, +++ thrice. ${ }^{a}$ Data from reference [21]. ${ }^{\mathrm{b}}$ Borderline minimum inhibitory concentration to ampicillin. AMP—ampicillin, ERYerythromycin, LEV-levofloxacin, CIP—ciprofloxacin, NAL—nalidixic acid, CTA—cefotaxime. In the tested conditions, the mutation frequency for the strains was $<10^{-9}$.

\subsection{Effect of Growth Conditions in the Transformation Frequency of Aliarcobacter butzleri}

In order to evaluate the factors influencing the natural transformation of A. butzleri, we used the DQ40A1 strain as recipient strain and biphasic system. To assess the effect of growth conditions on transformation frequency, different temperatures and atmospheric conditions were evaluated. The transformation was measured by the frequency of cells that acquired resistance to antibiotics.

A. butzleri DQ40A1 strain was naturally transformable at all the temperatures and atmospheric conditions tested, although at varying levels (Figure 1). The highest transformation frequency was obtained with incubation at $30^{\circ} \mathrm{C}$ in a microaerobic atmosphere, which was significantly higher than the obtained at 20 or $37^{\circ} \mathrm{C}, p<0.01$, while at $20^{\circ} \mathrm{C}$, under aerobic and microaerobic conditions, the frequency was significantly lower $(p<0.05)$. 


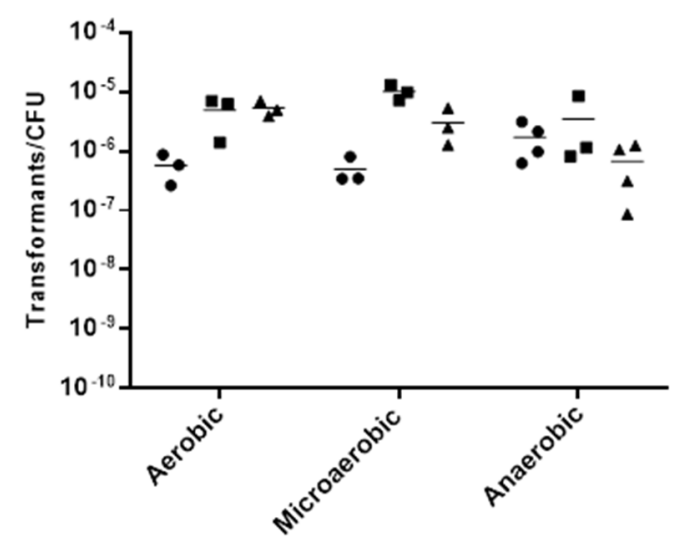

Figure 1. The effect of varying temperature $\left(\bullet 20^{\circ} \mathrm{C} ; \mathbf{\square} 30^{\circ} \mathrm{C} ; \mathbf{\Delta} 37^{\circ} \mathrm{C}\right)$ and atmospheric conditions in transformation frequency of Aliarcobacter butzleri DQ40A1, using $1 \mu \mathrm{g}$ of isogenic chromosomal DNA $\left(\mathrm{DQ} 40 \mathrm{~A} 1 \triangle \mathrm{areB}:: \mathrm{kan}^{R}\right)$. Results from at least three independent assays.

To further explore the transformation frequency according to $A$. butzleri growth, the donor DNA was added at different time sets after A. butzleri inoculation. The results show that $A$. butzleri is naturally transformable at all the tested periods and different growth phases, showing competence in the exponential and stationary phases; however, with higher efficiency during the initial phase of growth, when DNA was added at 2 or $6 \mathrm{~h}$ after inoculation (Figure 2). In fact, the transformation frequency was significantly higher when DNA was added at 6 hours after inoculation than at 24 or $48 \mathrm{~h}$ of incubation $(p<0.05)$.

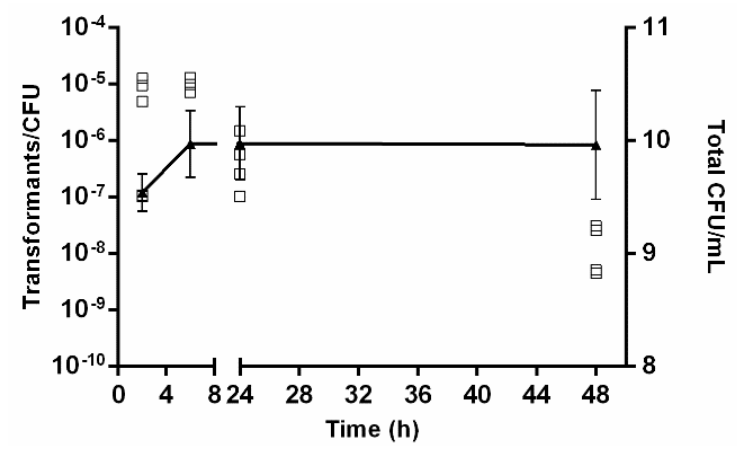

Figure 2. The growth curve and transformation frequencies of Aliarcobacter butzleri DQ40A1 strain. Growth was quantified by $\mathrm{CFU} / \mathrm{mL}$ counting $(\boldsymbol{\Lambda})$ being presented as mean \pm standard deviation, and transformation frequency was evaluated by adding isogenic chromosomal DNA $\left(\mathrm{DQ} 40 \mathrm{~A} 1 \mathrm{areB}:: \mathrm{kan}^{R}\right)$ at different time points $(\square)$. Results from at least three independent assays.

For the following studies, and unless otherwise stated, the assays were performed at $30{ }^{\circ} \mathrm{C}$, under microaerobic conditions, by adding donor DNA after $6 \mathrm{~h}$ of bacterial inoculation.

\subsection{Effect of DNA Concentration on Transformation Frequency of Aliarcobacter butzleri}

To evaluate whether the natural transformation was limited by the DNA concentration of the donor strain, increasing amounts of genomic DNA (gDNA) from A. butzleri DQ40A1 $\triangle a r e B:: k^{R}{ }^{R}$ mutant were used to transform A. butzleri DQ40A1 strain. The experiments with different DNA concentrations showed that transformation by isogenic donor DNA resulted in saturation, after a peak in the frequency of transformation was reached with $1000 \mathrm{ng}$ of donor DNA ( 7.65 $\times 10^{-6}$ transformants/CFU per $\mu \mathrm{g}$ of DNA) (Figure 3). The use of $1000 \mathrm{ng}$ of donor DNA led to a significantly higher frequency of transformation compared to the other tested concentrations $(p<0.001)$. The minimum quantity of DNA necessary to produce transformants was found to be $10 \mathrm{ng}$. 


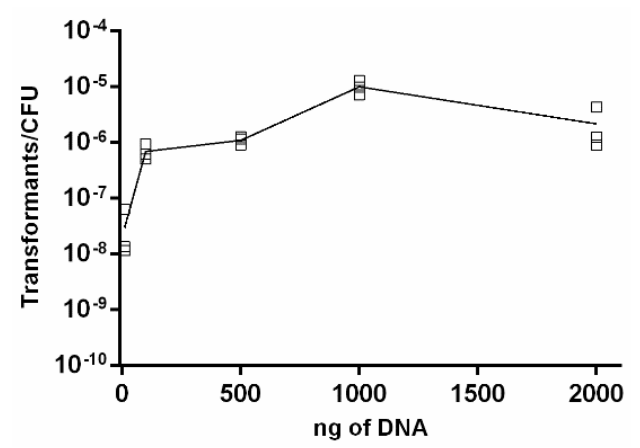

Figure 3. The effect of the quantity of donor DNA in the transformation frequency. The Aliarcobacter

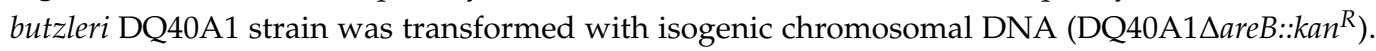
Results are from three independent assays $(\square)$.

\subsection{Transformation of Aliarcobacter butzleri with Different Donor DNA}

We further investigated the influence of the type of transforming DNA in the transformation frequency. For that, the naturally competent $A$. butzleri DQ40A1 strain was exposed to $1 \mu \mathrm{g}$ of different types of DNA molecules from the $344 \mathrm{bp}$ PCR fragments from different strains, corresponding to a fragment of the gyrA gene with the single nucleotide polymorphism C254T conferring resistance to ciprofloxacin or gDNA carrying the $\mathrm{Kan}^{R}$ resistance marker granting resistance to kanamycin (Table 2). We observed that the transformation frequency increased with donor DNA length and with isogenic material (Table 2). Although the transformation was possible with donor DNA from different strains, the results show that the homology between the donor DNA and the DNA of the recipient strain influences the transformation. The use of isogenic DNA is more efficient (CR1132 $\triangle a r e B:: k a n^{R}$ vs. DQ40A1 $\left.\triangle a r e B:: k a n^{R}\right)$, with transformation frequency being significantly higher than that obtained with the other donor DNA $(p<0.0001)$ (Table 2). When using gDNA from Campylobacter coli (873 isolate) containing a gentamicin resistance marker (aphA-3 gene) [22], no transformants were obtained (Table 2). These assays also showed that linear PCR fragments could serve as donor DNA without the need for vectors construction for transformation.

Table 2. Frequency of transformation of Aliarcobacter butzleri DQ40A1 strain using homologous and heterologous PCR fragments and genomic DNA.

\begin{tabular}{|c|c|c|c|}
\hline $\begin{array}{c}\text { Donor DNA } \\
\text { (Nature of DNA/Strain) }\end{array}$ & Resistance Marker & $\begin{array}{l}\text { Length of the PCR } \\
\text { Fragment }\end{array}$ & Transformants/CFU \\
\hline gDNA/Campylobacter coli 873 & aphA-3 & - & NT \\
\hline gyrA PCR fragment/Ab_2811 strain & C254T in gyrA gene & $344 \mathrm{bp}$ & $(6.70 \pm 2.72) \times 10^{-9}$ \\
\hline gyrA PCR fragment/Ab_2811 strain & C254T in gyrA gene & $1410 \mathrm{pb}$ & $(7.85 \pm 1.13) \times 10^{-8}$ \\
\hline gDNA/CR1132 $\triangle a r e B:: k^{R} n^{R}$ & $\begin{array}{c}a p h A-3\left(\mathrm{Kan}^{R} \text { cassette from }\right. \\
\text { pUC18-K2) }\end{array}$ & - & $(2.59 \pm 0.51) \times 10^{-7}$ \\
\hline $\begin{array}{c}\text { PCR fragment/of } \\
\text { DQ40A1 } 1 \text { areB::kan } R\end{array}$ & $\begin{array}{l}\text { aphA-3 }\left(\mathrm{Kan}^{R} \text { cassette from }\right. \\
\text { pUC18-K2), flanked by } \\
\text { upstream and downstream } \\
\text { regions of about } 400 \mathrm{bp}\end{array}$ & $1638 \mathrm{bp}$ & $(3.96 \pm 3.54) \times 10^{-7}$ \\
\hline gDNA/Ab_2811 strain & C254T in gyrA gene & - & $(6.92 \pm 7.67) \times 10^{-7}$ \\
\hline gDNA/DQ40A1 $\triangle a r e B:: k a n^{R}$ & $\begin{array}{c}a p h A-3\left(\mathrm{Kan}^{R} \text { cassette from }\right. \\
\text { pUC18-K2) }\end{array}$ & - & $(7.65 \pm 2.25) \times 10^{-6}$ \\
\hline
\end{tabular}




\subsection{Kinetics of Natural Transformation}

Kinetics of natural transformation was evaluated using $1 \mu \mathrm{g}$ of isogenic gDNA at $30{ }^{\circ} \mathrm{C}$ in microaerobic conditions with the biphasic system. The results showed that natural transformation occurred shortly after 15 min of incubation with the donor genetic material, and transformants were obtained at all the tested time points (Figure 4). A slow increase in transformation frequency was observed in the time frame from $15 \mathrm{~min}$ to $5 \mathrm{~h}$ raising from $(2.4 \pm 1.9) \times 10^{-7}$ to $(3.4 \pm 2.0) \times 10^{-6}$ transformants/total CFU.

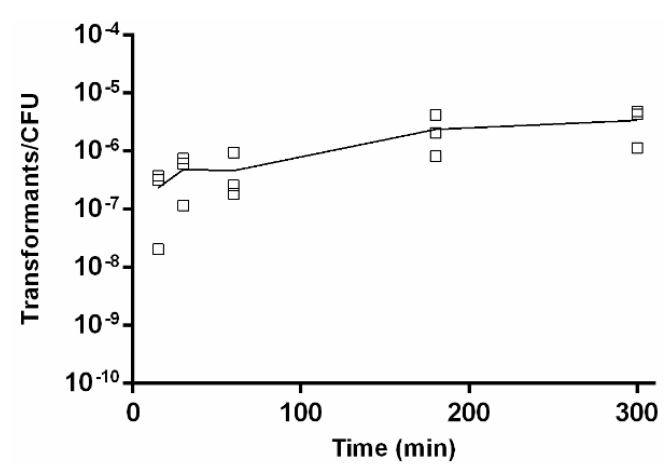

Figure 4. Kinetics of natural transformation. Aliarcobacter butzleri DQ40A1 strain transformed with isogenic genomic DNA (DQ40A1 $\triangle a r e B:: k a n^{R}$ ). The transformation was terminated by adding DNase I at various time points. Results are from three independent assays ( $\square$ ).

\subsection{Transfer of Antibiotic Resistance Determinants in Aliarcobacter butzleri Co-Cultures}

HGT has already been demonstrated in bacterial co-cultures for various bacterial species, such as $C$. jejuni [20]. In order to evaluate if transformation occurs in co-cultures of $A$. butzleri, we mixed the A. butzleri isogenic strain 851 carrying the C254T mutation in gyrA (conferring ciprofloxacin resistance) and the DQ40A1 $\triangle a r e B:: k a n^{R}$ mutant (conferring kanamycin resistance). Three hours of co-culture resulted in progenies resistant to both antibiotics, and in addition, there was an increase in the number of transformed colonies over time of culture, suggesting that the transference of genetic information proceeds during co-culture (Figure 5).

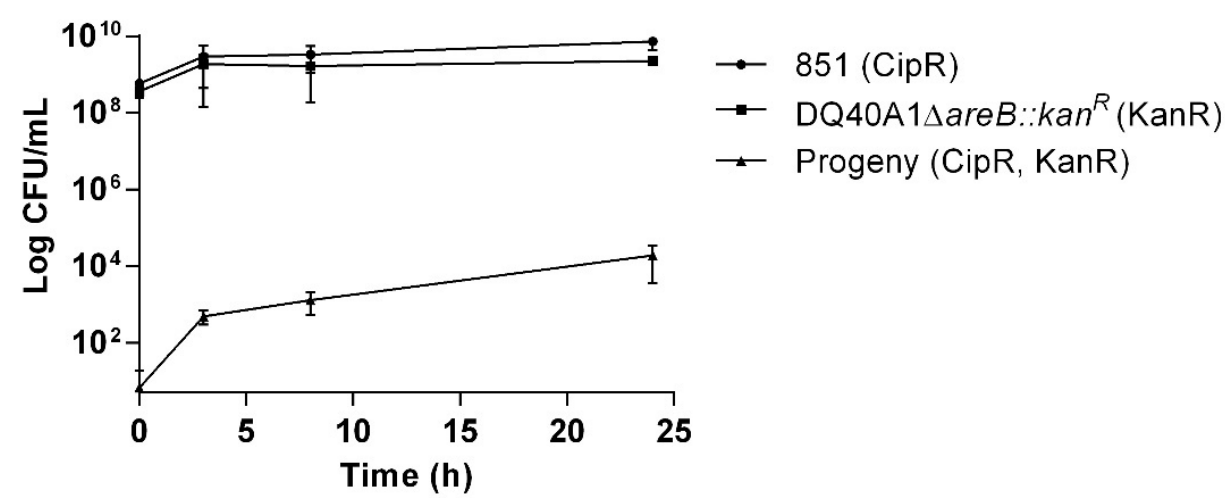

Figure 5. The transfer of antibiotic resistance determinants in co-cultures of Aliarcobacter butzleri carried out at $30{ }^{\circ} \mathrm{C}$ in microaerobic conditions. The progeny was evaluated by determining the number of cells resistant to both ciprofloxacin and kanamycin. Values are presented as mean \pm standard deviation.

\subsection{Identification of Putative Competence Genes in Aliarcobacter butzleri DQ40A1}

To investigate whether A. butzleri has the genetic machinery necessary for natural transformation, we searched the genome of $A$. butzleri DQ40A1 strain (GCA_902500765.1) for homologs of competence genes of $C$. jejuni, one of the best-studied species from the Campylobacteracea family regarding natural transformation $[17,23]$. Several homologs of genes known to be implicated in natural transformation in C. jejuni were found in the 
A. butzleri genome (Table 3). When no homologs of C. jejuni were found, we examined the A. butzleri DNA sequences against Neisseria gonorrhoeae proteins.

Overall, several homologs of genes encoding for DNA uptake, processing and other proteins related to the natural transformation process were found in the A. butzleri DQ40A1 genome. Considering the machinery associated with DNA uptake, it is recognized that some cts (for Campylobacter transformation system) proteins are involved in the transport of DNA for natural transformation across the outer membrane into the periplasm and over the inner membrane into the cytoplasm [17,23-25]. A. butzleri DQ40A1 harbors various homologs genes from $C$. jejuni machinery, namely a homolog of $c t s D$ from $C$. jejuni, which, in turn, is a homolog to pilQ of $N$. gonorrhoeae encoding for the outer membrane pore for DNA transport into the periplasm [25]. In addition, homologs of ctsG, pilG and ctsE were also found in A. butzleri genome. The product of $c t s G$ encodes for a putative pseudopilinlike protein in C. jejuni, while pilG is required for transformation and pilus biogenesis in $N$. gonorrhoeae [24,25], and ctsE encode putative nucleoside triphosphatases or nucleoside triphosphate binding protein [24]. Homologs of $c t s X$ and ctsP seem to be absent in the A. butzleri genome. The absence of homologs for $c t s P$ was also noticed for non-C. jejuni species, such as Campylobacter lari [17]. In contrast, a homolog of comEC, encoding for a predicted integral membrane channel for transport of DNA into the cytoplasm and considered essential for natural transformation in C. jejuni [26], can be found in A. butzleri genome. Moreover, a homolog of comE was found in the A. butzleri genome, whose product acts as a periplasmic DNA receptor contributing to the natural transformation of $C$. jejuni, however, is not considered essential for the process [27]. A homolog of PriA, shown to be involved in neisserial DNA transformation [28] was also found. Furthermore, A. butzleri carry genes coding for DNA processing machinery, such as the case of the homolog of the DNA processing A protein (DprA), described as having a role in DNA translocation, and which while being essential for transformation by chromosomal DNA in Haemophilus influenza [29], is not essential in Helicobacter pylori or C. jejuni [30,31]. Finally, homologs of other genes that may be associated with natural transformation in $C$. jejuni, although with a less established role [23], were found, namely $c t s W$, proC and ceuB, but with less than $50 \%$ of homology. 
Table 3. Competence protein homologs in the Aliarcobacter butzleri DQ40A1 strain.

\begin{tabular}{|c|c|c|c|c|c|c|}
\hline & Campylobacter jejuni & & $\begin{array}{c}\text { Aliarcobacter } \\
\text { butzleri RM4018 }\end{array}$ & Aliarcobacter & utzleri DQ40A & CDS) \\
\hline $\begin{array}{l}\text { Category and Homolog } \\
\text { (Locus ID) }\end{array}$ & Gene Product & Length (AA) & Homolog (Locus ID) & Homolog (Locus ID) & Length (AA) & 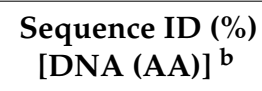 \\
\hline \multicolumn{7}{|c|}{ DNA Uptake } \\
\hline $\operatorname{cts} D(\mathrm{cj} 1474 \mathrm{c})$ & $\begin{array}{l}\text { Component of type II secretion/type IV pilus } \\
\text { system (potential outer membrane pore) }\end{array}$ & 472 & ABU_RS09160 & GDI89_RS08280 & 478 & $46.8(20.9)$ \\
\hline$c t s P(\mathrm{cj} 1473 \mathrm{c})$ & $\begin{array}{l}\text { Component of type II secretion/type IV pilus } \\
\text { system (putative NTPases/NTP binding protein) }\end{array}$ & 202 & NA & NA & NA & NA \\
\hline $\operatorname{cts} X(\mathrm{cj} 1472 \mathrm{c})$ & $\begin{array}{c}\text { Component of type II secretion/type IV pilus } \\
\text { system }\end{array}$ & 195 & NA & NA & NA & NA \\
\hline$c t s E(\mathrm{cj} 1471 \mathrm{c})$ & $\begin{array}{l}\text { Component of type II secretion/type IV pilus } \\
\text { system (putative NTPases/NTP binding protein) }\end{array}$ & 519 & ABU_RS08225 & GDI89_RS05100 & 453 & $53.5(36.1)$ \\
\hline pilG ${ }^{\mathrm{c}}$ & Competence pseudopilus & 410 & ABU_RS08220 & GDI89_RS05105 & 396 & $38.4(19.9)$ \\
\hline $\operatorname{cts} G(\mathrm{cj} 1343 \mathrm{c})$ & Putative periplasmic protein & 171 & ABU_RS03485 & GDI89_RS04080 & 132 & $47.5(28.1)$ \\
\hline $\operatorname{comEC}(\mathrm{cj} 1211)$ & $\begin{array}{l}\text { Membrane transporter protein involved in the } \\
\text { transfer of DNA across the membrane }\end{array}$ & 419 & ABU_RS06285 & GDI89_RS02780 & 409 & $56.6(36.2)$ \\
\hline $\operatorname{comE}(\mathrm{cj} 0011 \mathrm{c})$ & Periplasmic DNA-binding competence protein & 79 & ABU_RS11390 & GDI89_RS07505 & 123 & $43.7(31.7)$ \\
\hline \multicolumn{7}{|c|}{ DNA Processing } \\
\hline$d p r A(\mathrm{cj} 0634)$ & DNA processing protein & 257 & ABU_RS01180 & GDI89_RS06255 & 258 & $57.3(41.3)$ \\
\hline $\operatorname{rec} A$ & DNA recombination protein & 343 & ABU_RS11180 & GDI89_RS02220 & 349 & $73.5(73.4)$ \\
\hline \multicolumn{7}{|c|}{ Others } \\
\hline ctsT (cj1077) & Putative periplasmic protein & 100 & NA & NA & NA & NA \\
\hline ctsW (cj1028c) & Purine/pyrimidine phosphoribosyltransferase & 191 & ABU_RS02380 & GDI89_RS03920 & 190 & $59.2(44.0)$ \\
\hline $\operatorname{cts} R(\mathrm{cj} 1475 \mathrm{c})$ & Hypothetical protein & 105 & NA & NA & NA & NA \\
\hline proC (cj1076) & Putative PCA reductase & 243 & ABU_RS02955 & $\begin{array}{l}\text { NZ_CABVRU010000127.1 + } \\
\text { NZ_CABVRU010000230.1 }\end{array}$ & 254 & $53.1(40.5)$ \\
\hline сеив (cj1352) & Enterochelin uptake permease & 322 & ABU_RS05530 & GDI89_RS07350 & 320 & $49.1(25.4)$ \\
\hline
\end{tabular}

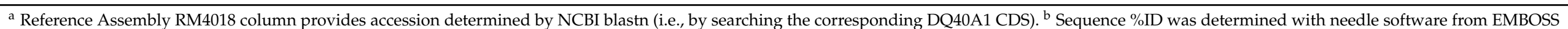

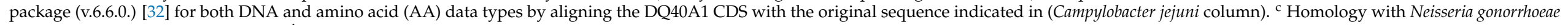
proteins of NZ_CP012028.1 genome. ${ }^{\mathrm{d}}$ The identified sequence is a partial CDS (truncated). ${ }^{\text {e }}$ Sequence assembled from two partial CDS obtained from described locus ID. NA-Not Available. 


\section{Discussion}

Natural transformation is a well-known mechanism of HGT that allows bacteria to acquire new genetic traits, resulting in genetic diversity among a population and contributing to adaptation to new environments and hosts $[12,25]$. For this process to occur, bacteria require to be naturally competent, having the ability to capture macromolecules of DNA from the environment and transfer them into a new cell where they will recombine with genomic DNA and replicate $[16,25,33]$. Several bacterial species have been described as naturally competent for transformation [16]; however, this has not yet been studied in A. butzleri. Furthermore, the genetic manipulation of A. butzleri has remained remarkably uncharacterized, with a small number of studies using genetic modification approaches.

The high genetic diversity of $A$. butzleri is likely associated with its natural competence for DNA uptake, which in turn can facilitate recombination between strains. To evaluate whether $A$. butzleri is naturally transformable, 17 strains were tested with two natural transformation methodologies. We found that $65 \%$ of the strains studied were naturally transformable with the agar method, e but only $47 \%$ using the biphasic procedure. Differences in the transformation capacity between strains of the same species have been reported for several bacterial species, including C. jejuni, C. coli [19,34], Haemophilus influenza [35], Gallibacterium anatis [36] or Actinobacillus actinomycetemcomitans [37]. In the present study, most of the isolates that showed detectable levels of natural transformation were from animal origin, more specifically from poultry. Kim et al. (2006) also found a dependence of the transformation capacity with the origin of the $C$. coli strain, with turkey-origin strains presenting higher transformation frequencies than swine-origin strains, likely due to differences in their genetic background or due to specific transformation requirements [34]. Another possible cause that can explain these results is the eventual presence of certain mechanisms, such as the secretion of endonucleases, that can limit the transformation in particular environments $[13,16,38]$.

The natural transformation process is considered to occur under normal growth conditions; however, it can suffer the influence of external factors [12,16] that can play an important role in transformation efficiency and frequency. Therefore, besides the genetic background of the strains, factors such as the growth phase, incubation conditions, and the nature, type and size of the donor genetic material are also relevant $[13,18,39,40]$.

Considering the temperature and atmosphere composition, these are two of the conditions impacting the process of natural transformation for several bacteria, such as $C$. jejuni [18]. Temperature had a greater influence in the frequency of A. butzleri transformation when compared to the atmospheric conditions, with a reduction of temperature resulting in a decrease in the number of transformants, under both aerobic and microaerobic conditions. Although A. butzleri was naturally transformable at all the temperatures and atmospheric conditions studied, even in limiting growth conditions, the most favorable conditions for the transformation of A. butzleri were established at $30^{\circ} \mathrm{C}$ in a microaerobic atmosphere. Accordingly, for $C$. jejuni, transformation was favored when carried out under the optimal growth conditions for these bacteria. Furthermore, for C. jejuni, the temperature also had a greater influence on the transformation frequency, when compared to the atmospheric conditions [18].

The results showed that $A$. butzleri is naturally competent for transformation during all the growth phases, with a maximum frequency of transformants being obtained when the genetic material was added at 2 or $6 \mathrm{~h}$ after bacterial inoculation. This profile was similar to that observed for other related bacteria, such as C. jejuni, C. coli or H. pylori, with the natural transformation occurring at all the growth phases as well, although for these species, the frequency of transformation reaches a peak at the mid-exponential phase [18,19,41]. However, the regulatory pathways of natural transformation are divergent according to bacterial species/genera [13,42], and the most efficient process can occur at different growth phases, either when DNA is added prior to the exponential phase [41], during the exponential phase $[18,19,43,44]$ or during the late-log to mid-stationary phase [42]. 
In the environment, bacteria are kept in contact with diverse concentrations of genetic material that may influence the frequency of natural transformation. In A. butzleri, the number of transformants was directly correlated with the concentration of the donor genetic material, reaching a maximum with the use of $1 \mu \mathrm{g}$ of gDNA. This amount of DNA was also described for other Gram-negative bacteria, such as C. jejuni, C. coli and G. anatis, as being necessary to reach the highest number of transformants [19,36], while other species require much less, such as H. pylori, for which 6 ng of gDNA was described [41].

The size and homology of the donor DNA can also have an impact on natural transformation since homologous recombination is required for efficient incorporation of the uptaked DNA. Regarding size, the decrease in fragment size is associated with a decrease in the region available for homologous recombination between the donor and the recipient DNA, resulting in a reduction of transformation efficiency [45]. This was observed in our study as well since when using isogenic DNA as donor genetic material, a lower number of transformants was obtained with a PCR fragment than with gDNA. This occurs despite the higher number of copies of the selective marker present in the PCR fragments when compared to the number of copies present in gDNA with the same concentration. These results may indicate that the greater the extent of homology between the incorporated sequences and the bacterial recipient genome, the greater the probability of hybridizing with the bacterial genome and, consequently, obtaining a more efficient transformation.

The nature of the donor DNA was also evaluated, and when donor DNA from C. coli was used, no transformants were obtained, similarly to what happens for C. jejuni, for which the addition of increasing concentrations of A. butzleri gDNA did not originate transformants [18]. This negative result is likely associated with insufficient lack of homology between the gDNA of these species and with the presence of defense mechanisms, such as restriction-modification systems [11]. Overall, the results suggest that HGT via natural transformation between different species is less probable than within a species.

The transformation kinetics assays showed that $A$. butzleri uptake of DNA from the environment is a fast process, as described for other bacteria, such as C. jejuni, C. coli or A. calcoaceticus $[18,19,46]$. In addition, a gradual increase in the number of transformants over time was observed, mimicking the process that occurs in Campylobacter spp. [18,19].

HGT also contributes to the transmission and spread of resistance determinants among bacterial communities [47]. For example, C. jejuni is capable of transferring resistance determinants in co-cultures without the addition of genetic material in the culture medium [20]. This phenomenon was also observed in the present study, with the exchange of chromosomally encoded antibiotic resistance determinants during a co-culture of different $A$. butzleri strains. The increase in the number of transformants observed during the co-culture can result from the constant release of DNA into the medium through cell lysis, similar to what happens in C. jejuni $[20,26]$. Thus, it is very likely that natural transformation plays a role in the transfer of genetic material, including antimicrobial resistance, among $A$. butzleri strains.

Regarding transformation machinery, the previous analysis of the A. butzleri genome showed the presence of putative competence genes [10]. Moreover, it was previously suggested that homologs of the comEC gene, encoding for a periplasmic DNA receptor contributing to the natural transformation [26], are present in the core genome of naturally transformable Gram-negative species [48]. In the present study, a homolog of the comEC gene was found in the $A$. butzleri genome, sharing $57 \%$ similarity with the homolog gene in C. jejuni. Other homologs genes encoding for proteins essential for DNA uptake and processing were also identified in the A. butzleri genome, corroborating the natural competence for the transformation of this bacterium. Nonetheless, machinery required for natural transformation may also be encoded by divergent homologs or unrelated proteins with the same function, a subject that needs to be further explored.

In summary, the present study demonstrated, for the first time, that A. butzleri is a naturally transformable bacterium and brought knowledge regarding the natural transformation process, pointing out this process as a way of HGT within this species. A protocol 
to improve the molecular research of this microorganism was also established, providing a new tool for genetic manipulation of this bacterium. Nonetheless, despite the advances in our understanding of the natural transformation of A. butzleri, more studies are needed to unveil the mechanisms involved in the process and towards improving knowledge about the contribution of the natural transformation process to the diversity and genetic adaptation of $A$. butzleri.

\section{Materials and Methods}

\subsection{Bacterial Strains and Growth Conditions}

The A. butzleri recipient strains used in this work, as well as their origin and characteristics, are shown in Table 1 . Two of the donor strains, DQ40A1 areB::kan $^{R}$ and CR1132 $\triangle a r e B:: k^{R} n^{R}$, were generated by the insertion of a kanamycin resistance cassette (aphA-3) interrupting the areB gene (ABU_RS11090). The aphA-3_cassette was obtained by BamHI and KpnI double digestion of the pUC18-K2 plasmid, followed by binding to the upstream and downstream region of the areB gene by overlap-extension PCR. The purified PCR fragment was used for mutant construction by the agar transformation method, as described elsewhere [49]. The A. butzleri 851 gyr A mutant strain was generated by transformation of the DQ40A1 strain with a 344 bp PCR fragment of the gyrA gene, carrying the single nucleotide polymorphism (C254T) conferring resistance to ciprofloxacin.

A. butzleri strains were routinely cultured on Blood Agar Base (Oxoid, Basingstoke, England) supplemented with 5\% defibrinated horse blood $(v / v)$ (BA-Blood Agar). The bacteria were incubated at $30{ }^{\circ} \mathrm{C}$ in a controlled atmosphere $\left(6 \% \mathrm{O}_{2}, \pm 7.1 \% \mathrm{CO}_{2}\right.$ and $3.6 \%$ $\mathrm{H}_{2}$ ) generated by an atmosphere modifier (Anoxomat AN2CTS, Mart Microbiology B.V., Drachten, Netherlands), unless otherwise stated. For transformants selection, strains were transferred to BA plates containing $4 \mu \mathrm{g} / \mathrm{mL}$ of ciprofloxacin, or 30 and $50 \mu \mathrm{g} / \mathrm{mL}$ of kanamycin, or both antibiotics.

\subsection{Genetic Material Preparation}

Different genetic material was used for the transformation assays: gDNA of $A$. butzleri $\mathrm{Ab}$ 2811, DQ40A1 $\triangle a r e B:: k^{R}{ }^{R}$ and CR1132 $\Delta a r e B:: k^{R} n^{R}$ strains, and purified PCR fragments with different sizes resulting from amplification of both the gyrA gene of $A$. butzleri Ab_2811 strain and the $a r e B$ gene of DQ40A1 $\triangle a r e B:: k a n^{R}$ strain. Genomic DNA from C. coli 873 was also used. The GF-1 Nucleic Acid Extraction Kit (Vivantis, Shah Alam, Malaysia) was used for gDNA extraction. Primers specified in Table 4 were used for PCR amplification. The genetic material obtained was quantified using a nanoespectrophotometer, and its integrity and purity were analyzed through an agarose gel.

Table 4. The primers used in PCR in this study.

\begin{tabular}{|c|c|c|c|}
\hline Primers & Sequence & $\begin{array}{l}\text { Size of Amplified } \\
\text { Fragment (bp) }\end{array}$ & Reference \\
\hline gyrA_Fw & TGGACGTGCATTACCAGATG & \multirow{2}{*}{1410} & \multirow{2}{*}[50]{} \\
\hline gyrA_Rv & GCAАСТTTTCСТTTТССАССТ & & \\
\hline F-QRDR & TGGATTAAAGCCAGTTCATAGAAG & \multirow{2}{*}{344} & \multirow{2}{*}{ [51] } \\
\hline R2-QRDR & TCATMGWATCATCATAATTTGGWAC & & \\
\hline areB_A1 & TTGAAATAAGGGCTACTTACTCAGG & \multirow{2}{*}{1638} & \multirow{2}{*}{ [49] } \\
\hline areB_B2 & GTTCGCTCTGGCTTGCAAAT & & \\
\hline
\end{tabular}

\subsection{Natural Transformation Using the Agar Transformation Method}

Seventeen $A$. butzleri strains were tested using a natural transformation protocol in a solid medium. Initially, each of the strains was cultured on BA plates and incubated for $24 \mathrm{~h}$ at $30{ }^{\circ} \mathrm{C}$ under microaerobic atmospheric conditions. After incubation, the cells were resuspended in $200 \mu \mathrm{L}$ of Tryptic Soy Broth (TSB, Merck, Darmstadt, Germany) and spread 
on BA plates, incubated for a further $4 \mathrm{~h}$ under the same conditions. In two distinct areas of the plates, $1 \mu \mathrm{g}$ of gDNA from $A$. butzleri DQ40A1 $\operatorname{areB}:: \mathrm{kan}^{R}$ strain was added in a volume of $40 \mu \mathrm{L}$, and plates were incubated for $8 \mathrm{~h}$ under the above conditions. Negative controls were performed, replacing gDNA with water. Subsequently, the cultures were transferred to another BA plate and incubated for $18 \mathrm{~h}$. After this incubation period, the biomass was transferred to PBS and applied to BA plates supplemented with $50 \mu \mathrm{g} / \mathrm{mL}$ of kanamycin. These plates were incubated for 3-7 days. The assays were performed on three independent days. The occurrence of natural transformation was confirmed for a few clones in each transformation by PCR using the primers areB_A1 and areB_B2, followed by fragment size assessment through gel electrophoresis.

\subsection{Natural Transformation Using a Biphasic System}

The natural transformation was also performed using a biphasic system, based on the protocol described for Campylobacter by Wang \& Taylor (1990), with modifications [19]. Briefly, after growth on BA plates for $24 \mathrm{~h}$, the A. butzleri DQ40A1 strain at approximately $5 \times 10^{8} \mathrm{CFU} / \mathrm{mL}$ in $200 \mu \mathrm{L}$ of TSB was transferred to test tubes containing $1.5 \mathrm{~mL}$ of BA and incubated for $6 \mathrm{~h}$ at $30^{\circ} \mathrm{C}$ under microaerobic conditions. Subsequently, $1 \mu \mathrm{g}$ of genetic material, or $40 \mu \mathrm{L}$ of water in the control, was added to the tubes and incubated again for a further $5 \mathrm{~h}$. Next, the cells were harvested and diluted in phosphate-buffered saline (PBS), and appropriated dilutions were transferred onto selective and non-selective BA plates. After incubation for 5 days, colonies were counted, and the transformation frequency was calculated. This assay was performed on three independent days. The transformation was verified by PCR for selected clones. This protocol was also used for screening natural transformation in the 17 isolates of $A$. butzleri under study, using $1 \mu \mathrm{g}$ of gDNA from the donor A. butzleri DQ40A1 $\Delta a r e B:: k^{R}{ }^{R}$ strain.

\subsection{Effect of Growth Conditions}

The influence of temperature and atmospheric conditions or growth phase on the transformation frequency of $A$. butzleri was determined using the biphasic system. For that, temperatures of 20,30 and $37^{\circ} \mathrm{C}$, and aerobic, microaerobic and anaerobic conditions, were tested. Regarding the growth phase, $A$. butzleri DQ40A1 cells were incubated for 2, 6, 24 and $48 \mathrm{~h}$ before the addition of gDNA. After the incubation periods, a count of the total $\mathrm{CFU} / \mathrm{mL}$ was performed, and then the gDNA of $A$. butzleri DQ40A1 $\triangle a r e B:: k^{R} n^{R}$ strain was added as described above. The transformation frequencies were calculated and compared. The assays were performed at least three independent times.

\subsection{Kinetics of Natural Transformation}

To evaluate the kinetics of natural transformation in A. butzleri DQ40A1 strain, the biphasic protocol was used, adding to each tube $1 \mu \mathrm{g}$ of gDNA from the A. butzleri DQ40A1 $\triangle a r e B:: k^{R} n^{R}$ strain carrying the resistance kanamycin marker, and incubation at $30{ }^{\circ} \mathrm{C}$ under microaerobic conditions. Each individual transformation assay was terminated at times $0,15,30,60,180$ and $300 \mathrm{~min}$ by the addition of $100 \mu \mathrm{g} / \mathrm{mL}$ DNase, after which a period of incubation of $2 \mathrm{~h}$ was followed, under the previously described conditions, for phenotypic expression [18]. Finally, the transformation frequency was determined, transferring $100 \mu \mathrm{L}$ of the culture or dilutions to selective plates and for non-selective BA plates. This assay was performed three independent times.

\subsection{Influence of Genetic Material on Natural Transformation}

A saturation curve was performed at $30{ }^{\circ} \mathrm{C}$ and a microaerobic atmosphere, using the biphasic system protocol, with various concentrations of exogenous gDNA from the donor A. butzleri DQ40A1 $\triangle a r e B:: k a n^{R}$ strain. The following different quantities of gDNA, $0.01,0.1,0.5,1$ and $2 \mu \mathrm{g}$, were added to the culture, using $A$. butzleri DQ40A1 as a receptor strain. Furthermore, the influence of different types of genetic material was tested using amplified PCR fragments of $A$. butzleri Ab_2811 and DQ40A1 $\Delta a r e B:: k a n^{R}$ strains, as well 
as the gDNA previously extracted of $A$. butzleri CR1132 $\Delta a r e B:: k a n^{R}$, DQ40A1 $\triangle a r e B:: k a n^{R}$, $A b \_2811$ and $C$. coli 873 strains. Each assay was performed on three independent days.

\subsection{Exchange of Genetic Material Between Bacterial Co-Cultures}

For co-culture experiments, the strains of A. butzleri 851 (ciprofloxacin-resistant) and DQ40A1 $\triangle a_{\text {reB:: }} \mathrm{kan}^{R}$ (kanamycin-resistant) were collected from BA plates after $24 \mathrm{~h}$ of incubation and settled to grow together in the biphasic system at $30^{\circ} \mathrm{C}$ and microaerobic atmosphere. From each culture, $5 \times 10^{8} \mathrm{CFU} / \mathrm{mL}$ in $200 \mu \mathrm{L}$ of TSB were added to the test tubes containing $1.5 \mathrm{~mL}$ of BA medium, and independent tubes were prepared for each incubation time (0, 3, 8 and $24 \mathrm{~h})$. At each time, a sample was taken, and successive dilutions were carried out in PBS. Successive dilutions were then transferred to BA plates, supplemented with $30 \mu \mathrm{g} / \mathrm{mL}$ kanamycin or $4 \mu \mathrm{g} / \mathrm{mL}$ ciprofloxacin, to count the CFU $/ \mathrm{mL}$ of each strain, or to BA plates supplemented with both antibiotics, to count the CFU $/ \mathrm{mL}$ of the double resistant bacteria. Assays were performed on three independent days.

\subsection{Bioinformatics Analyses-Identification of Homologs Genes Presence/Absence}

The predicted CDS of competence genes from the bacterial genomes of Campylobacter jejuni and Neisseria gonorrhoeae, were downloaded from NCBI Genbank. The genome assembly of the A. butzleri DQ40A1 strain was locally formatted using NCBI BLAST tools [52]. The CDS set (queries) from each species were translated (translation table $=11$ ) and searched against the genome using tBLASTn (v.2.9.0) [53] (option -db_gencode 11). The results were screened by employing an E-value threshold of 1e-4. The contigs identified in this procedure were then retrieved in full from the genome and compiled as a separate library which was used as input for Prodigal (V2.6.3) [54] software (-p meta option) to identify and retrieve all suitable CDS, by matching through the identified tBLASTn best hits.

The NCBI nr database using blastx webservice limited to A. butzleri (taxid 28197) was employed to ensure that the identified CDS were homologous and presented similar functions to the queries.

Author Contributions: Conceptualization, S.F.; formal analysis, M.B., S.F.; software, E.M.; investigation, M.B., C.M., A.R.A.; writing-original draft preparation, M.B., C.M.; writing-review and editing, F.D., M.O., S.F.; supervision, F.D., M.O., S.F.; funding acquisition, A.P.D., F.D., S.F. All authors have read and agreed to the published version of the manuscript.

Funding: This work was supported by the Foundation for Science and Technology (FCT), through funds from the State Budget, and by the European Regional Development Fund (ERDF), under the Portugal 2020 Program, through the Regional Operational Program of the Center (Centro2020), through the Project with the reference UIDB/00709/2020. This work was also funded by the operation CENTRO-01-0145-FEDER-000019 - C4 - Centro de Competências em Cloud Computing, supported by the European Regional Development Fund (ERDF) through the Regional Operational Program of the Center (Centro2020). Cristiana Mateus is the recipient of a doctoral fellowship (UI/BD/151023/2021) under the scope of the CICS-UBI Programmatic Funding (UIDP/00709/2020). Susana Ferreira acknowledges the Universidade da Beira Interior and FCT by the contract of Scientific Employment according to DL57/2016.

Institutional Review Board Statement: Not applicable.

Informed Consent Statement: Not applicable.

Data Availability Statement: Data are contained within the text.

Conflicts of Interest: The authors declare no conflict of interest.

\section{References}

1. Vandamme, P.; Falsen, E.; Rossau, R.; Hoste, B.; Segers, P.; Tytgat, R.; De Ley, J. Revision of Campylobacter, Helicobacter, and Wolinella taxonomy: Emendation of generic descriptions and proposal of Arcobacter gen. nov. Int. J. Syst. Bacteriol. 1991, 41, 88-103. [CrossRef] [PubMed]

2. Pérez-Cataluña, A.; Salas-Massó, N.; Diéguez, A.L.; Balboa, S.; Lema, A.; Romalde, J.L.; Figueras, M.J. Revisiting the taxonomy of the genus Arcobacter: Getting order from the chaos. Front. Microbiol. 2018, 9, 2077. [CrossRef] 
3. Waite, D.W.; Vanwonterghem, I.; Rinke, C.; Parks, D.H.; Zhang, Y.; Takai, K.; Sievert, S.M.; Simon, J.; Campbell, B.J.; Hanson, T.E.; et al. Comparative genomic analysis of the class Epsilonproteobacteria and proposed reclassification to Epsilonbacteraeota (phyl. nov.). Front. Microbiol. 2017, 8, 682. [CrossRef]

4. Collado, L.; Figueras, M.J. Taxonomy, epidemiology, and clinical relevance of the genus Arcobacter. Clin. Microbiol. Rev. 2011, 24, 174-192. [CrossRef]

5. Ferreira, S.; Queiroz, J.A.; Oleastro, M.; Domingues, F.C. Insights in the pathogenesis and resistance of Arcobacter: A review. Crit. Rev. Microbiol. 2016, 42, 364-383.

6. Van den Abeele, A.M.; Vogelaers, D.; Van Hende, J.; Houf, K. Prevalence of Arcobacter species among humans, Belgium, 2008-2013. Emerg. Infect. Dis. 2014, 20, 1731-1734. [CrossRef]

7. Collado, L.; Gutiérrez, M.; González, M.; Fernández, H. Assessment of the prevalence and diversity of emergent campylobacteria in human stool samples using a combination of traditional and molecular methods. Diagn. Microbiol. Infect. Dis. 2013, 75, 434-436. [CrossRef]

8. Ferreira, S.; Júlio, C.; Queiroz, J.A.; Domingues, F.C.; Oleastro, M. Molecular diagnosis of Arcobacter and Campylobacter in diarrhoeal samples among Portuguese patients. Diagn. Microbiol. Infect. Dis. 2014, 78, 220-225. [CrossRef] [PubMed]

9. Vandenberg, O.; Dediste, A.; Houf, K.; Ibekwem, S.; Souayah, H.; Cadranel, S.; Douat, N.; Zissis, G.; Butzler, J.-P.; Vandamme, P. Arcobacter species in humans. Emerg. Infect. Dis. 2004, 10, 1864-1867. [CrossRef] [PubMed]

10. Miller, W.G.; Parker, C.T.; Rubenfield, M.; Mendz, G.L.; Wösten, M.M.S.M.; Ussery, D.W.; Stolz, J.F.; Binnewies, T.T.; Hallin, P.F.; Wang, G.; et al. The complete genome sequence and analysis of the epsilonproteobacterium Arcobacter butzleri. PLoS ONE 2007, 2, e1358. [CrossRef]

11. Thomas, C.M.; Nielsen, K.M. Mechanisms of, and barriers to, horizontal gene transfer between bacteria. Nat. Rev. Microbiol. 2005, 3, 711-721. [CrossRef]

12. Chen, I.; Dubnau, D. DNA uptake during bacterial transformation. Nat. Rev. Microbiol. 2004, 2, 241-249. [CrossRef] [PubMed]

13. Seitz, P.; Blokesch, M. Cues and regulatory pathways involved in natural competence and transformation in pathogenic and environmental Gram-negative bacteria. FEMS Microbiol. Rev. 2013, 37, 336-363. [CrossRef] [PubMed]

14. Lorenz, M.G.; Wackernagel, W. Bacterial gene transfer by natural genetic transformation in the environment. Microbiol. Rev. 1994, 58, 563-602. [CrossRef]

15. Dubnau, D. DNA uptake in bacteria. Annu. Rev. Microbiol. 1999, 53, 217-244. [CrossRef] [PubMed]

16. Blokesch, M. Natural competence for transformation. Curr. Biol. 2016, 26, R1126-R1130. [CrossRef] [PubMed]

17. Golz, J.C.; Stingl, K. Natural competence and horizontal gene transfer in Campylobacter. In Current Topics in Microbiology and Immunology; Backert, S., Ed.; Springer International Publishing: Cham, Switzerland, 2021; Volume 431, pp. 265-292. ISBN 9783030654818.

18. Vegge, C.S.; Brøndsted, L.; Ligowska-Marzeta, M.; Ingmer, H. Natural transformation of Campylobacter jejuni occurs beyond limits of growth. PLoS ONE 2012, 7, 1-10. [CrossRef]

19. Wang, Y.; Taylor, D.E. Natural transformation in Campylobacter species. J. Bacteriol. 1990, 172, 949-955. [CrossRef]

20. Wilson, D.L.; Bell, J.A.; Young, V.B.; Wilder, S.R.; Mansfield, L.S.; Linz, J.E. Variation of the natural transformation frequency of Campylobacter jejuni in liquid shake culture. Microbiology 2003, 149, 3603-3615. [CrossRef]

21. Isidro, J.; Ferreira, S.; Pinto, M.; Domingues, F.; Oleastro, M.; Gomes, J.P.; Borges, V. Virulence and antibiotic resistance plasticity of Arcobacter butzleri: Insights on the genomic diversity of an emerging human pathogen. Infect. Genet. Evol. 2020, 80, 104213. [CrossRef]

22. Duarte, A.; Santos, A.; Manageiro, V.; Martins, A.; Fraqueza, M.J.; Caniça, M.; Domingues, F.C.; Oleastro, M. Human, food and animal Campylobacter spp. isolated in Portugal: High genetic diversity and antibiotic resistance rates. Int. J. Antimicrob. Agents 2014, 44, 306-313. [CrossRef]

23. Gilbreath, J.J.; Cody, W.L.; Merrell, D.S.; Hendrixson, D.R. Change is good: Variations in common biological mechanisms in the Epsilonproteobacterial genera Campylobacter and Helicobacter. Microbiol. Mol. Biol. Rev. 2011, 75, 84-132. [CrossRef]

24. Beauchamp, J.M.; Erfurt, R.S.; Di Rita, V.J. Characterization and localization of the Campylobacter jejuni transformation system proteins CtsE, CtsP, and CtsX. J. Bacteriol. 2015, 197, 636-645. [CrossRef]

25. Wiesner, R.S.; Hendrixson, D.R.; Di Rita, V.J. Natural transformation of Campylobacter jejuni requires components of a type II secretion system. J. Bacteriol. 2003, 185, 5408-5418. [CrossRef]

26. Jeon, B.; Muraoka, W.; Sahin, O.; Zhang, Q. Role of Cj1211 in natural transformation and transfer of antibiotic resistance determinants in Campylobacter jejuni. Antimicrob. Agents Chemother. 2008, 52, 2699-2708. [CrossRef]

27. Jeon, B.; Zhang, Q. Cj0011c, a periplasmic single- and double-stranded DNA-binding protein, contributes to natural transformation in Campylobacter jejuni. J. Bacteriol. 2007, 189, 7399-7407. [CrossRef]

28. Kline, K.A.; Seifert, H.S. Mutation of the priA gene of Neisseria gonorrhoeae affects DNA transformation and DNA repair. J. Bacteriol. 2005, 187, 5347-5355. [CrossRef]

29. Karudapuram, S.; Zhao, X.; Barcak, G.J. DNA sequence and characterization of Haemophilus influenzae dprA+, a gene required for chromosomal but not plasmid DNA transformation. J. Bacteriol. 1995, 177, 3235-3240. [CrossRef]

30. Takata, T.; Ando, T.; Israel, D.A.; Wassenaar, T.M.; Blaser, M.J. Role of dprA in transformation of Campylobacter jejuni. FEMS Microbiol. Lett. 2005, 252, 161-168. [CrossRef] 
31. Ando, T.; Israel, D.A.; Kusugami, K.; Blaser, M.J. HP0333, a member of the dprA family, is involved in natural transformation in Helicobacter pylori. J. Bacteriol. 1999, 181, 5572-5580. [CrossRef] [PubMed]

32. Rice, P.; Longden, L.; Bleasby, A. EMBOSS: The European Molecular Biology Open Software Suite. Trends Genet. 2000, 16, $276-277$. [CrossRef]

33. Mell, J.C.; Redfield, R.J. Natural competence and the evolution of DNA uptake specificity. J. Bacteriol. 2014, 196, 1471-1483. [CrossRef]

34. Kim, J.S.; Carver, D.K.; Kathariou, S. Natural transformation-mediated transfer of erythromycin resistance in Campylobacter coli strains from Turkeys and swine. Appl. Environ. Microbiol. 2006, 72, 1316-1321. [CrossRef] [PubMed]

35. Maughan, H.; Redfield, R.J. Extensive variation in natural competence in Haemophilus influenzae. Evolution 2009, 63, 1852-1866. [CrossRef] [PubMed]

36. Kristensen, B.M.; Sinha, S.; Boyce, J.D.; Bojesen, A.M.; Mell, J.C.; Redfield, R.J. Natural transformation of Gallibacterium anatis. Appl. Environ. Microbiol. 2012, 78, 4914-4922. [CrossRef] [PubMed]

37. Wang, Y.; Goodman, S.D.; Redfield, R.J.; Chen, C. Natural transformation and DNA uptake signal sequences in Actinobacillus actinomycetemcomitans. J Bacteriol. 2002, 184, 3442-3449. [CrossRef] [PubMed]

38. Gaasbeek, E.J.; Wagenaar, J.A.; Guilhabert, M.R.; Van Putten, J.P.M.; Parker, C.T.; Van Der Wal, F.J. Nucleases encoded by the integrated elements CJIE2 and CJIE4 inhibit natural transformation of Campylobacter jejuni. J. Bacteriol. 2010, 192, 936-941. [CrossRef] [PubMed]

39. Sikorski, J.; Teschner, N.; Wackernagel, W. Highly different levels of natural transformation are associated with genomic subgroups within a local population of Pseudomonas stutzeri from soil. Appl. Environ. Microbiol. 2002, 68, 865-873. [CrossRef]

40. Huddleston, J.R.; Brokaw, J.M.; Zak, J.C.; Jeter, R.M. Natural transformation as a mechanism of horizontal gene transfer among environmental Aeromonas species. Syst. Appl. Microbiol. 2013, 36, 224-234. [CrossRef]

41. Israel, D.A.; Lou, A.S.; Blaser, M.J. Characteristics of Helicobacter pylori natural transformation. FEMS Microbiol. Lett. 2000, 188, 275-280. [CrossRef] [PubMed]

42. Dai, K.; He, L.; Chang, Y.F.; Cao, S.; Zhao, Q.; Huang, X.; Wu, R.; Huang, Y.; Yan, Q.; Han, X.; et al. Basic characterization of natural transformation in a highly transformable Haemophilus parasuis strain SC1401. Front. Cell. Infect. Microbiol. 2018, 8, 1-18. [CrossRef]

43. Liu, M.F.; Zhang, L.; Huang, L.; Biville, F.; Zhu, D.K.; Wang, M.S.; Jia, R.Y.; Chen, S.; Sun, K.F.; Yang, Q.; et al. Use of natural transformation to establish an easy knockout method in Riemerella anatipestifer. Appl. Environ. Microbiol. 2017, 83. [CrossRef]

44. Vesel, N.; Blokesch, M. Pilus production in Acinetobacter baumannii is growth phase dependent and essential for natural transformation. J. Bacteriol. 2021, 203. [CrossRef]

45. De Vries, J.; Meier, P.; Wackernagel, W. The natural transformation of the soil bacteria Pseudomonas stutzeri and Acinetobacter sp. by transgenic plant DNA strictly depends on homologous sequences in the recipient cells. FEMS Microbiol. Ecol. 2001, 195, $211-215$. [CrossRef]

46. Palmen, R.; Buijsman, P.; Hellingwerf, K.J. Physiological regulation of competence induction for natural transformation in Acinetobacter calcoaceticus. Arch. Microbiol. 1994, 162, 344-351. [CrossRef]

47. Van Hoek, A.H.A.M.; Mevius, D.; Guerra, B.; Mullany, P.; Roberts, A.P.; Aarts, H.J.M. Acquired antibiotic resistance genes: An overview. Front. Microbiol. 2011, 2, 203. [CrossRef] [PubMed]

48. Johnston, C.; Martin, B.; Fichant, G.; Polard, P.; Claverys, J.P. Bacterial transformation: Distribution, shared mechanisms and divergent control. Nat. Rev. Microbiol. 2014, 12, 181-196. [CrossRef] [PubMed]

49. Ferreira, S.; Silva, A.L.; Tomás, J.; Mateus, C.; Domingues, F.; Oleastro, M. Characterization of AreABC, an RND-type efflux system involved in antimicrobial resistance of Aliarcobacter butzleri. Antimicrob. Agents Chemother. 2021. accepted for publication. [CrossRef] [PubMed]

50. Kim, H.M.; Hwang, C.Y.; Cho, B.C. Arcobacter marinus sp. nov. Int. J. Syst. Evol. Microbiol. 2010, 60, 531-536. [CrossRef]

51. Abdelbaqi, K.; Ménard, A.; Prouzet-Mauleon, V.; Bringaud, F.; Lehours, P.; Mégraud, F. Nucleotide sequence of the gyrA gene of Arcobacter species and characterization of human ciprofloxacin-resistant clinical isolates. FEMS Immunol. Med. Microbiol. 2007, 49, 337-345. [CrossRef] [PubMed]

52. Camacho, C.; Coulouris, G.; Avagyan, V.; Ma, N.; Papadopoulos, J.; Bealer, K.; Madden, T.L. BLAST+: Architecture and applications. BMC Bioinform. 2009, 10, 1-9. [CrossRef] [PubMed]

53. Altschul, S.F.; Madden, T.L.; Schäffer, A.A.; Zhang, J.; Zhang, Z.; Miller, W.; Lipman, D.J. Gapped BLAST and PSI-BLAST: A new generation of protein database search programs. Nucleic Acids Res. 1997, 25, 3389-3402. [CrossRef] [PubMed]

54. Hyatt, D.; Chen, G.L.; Lo Cascio, P.F.; Land, M.L.; Larimer, F.W.; Hauser, L.J. Prodigal: Prokaryotic gene recognition and translation initiation site identification. BMC Bioinform. 2010, 11, 119. [CrossRef] 